\title{
Plant Water Potential for Shrubs in Argentina
}

\author{
DANIEL V. PELAEZ AND ROBERTO M. Bóo
}

\begin{abstract}
Water relations of Prosopis flexuosa, $\boldsymbol{P}$. caldenia, Condalia microphylla, Larrea divaricata, and Chuquiraga erinacea, 5 shrub species of a temperate semiarid region of Argentina were analyzed by periodic measurement of soil water potential, plant water potential, and air humidity. Water potential in all species showed recovery during the night, the values obtained early in the morning being higher (less negative) than those recorded in the afternoon. Plant water potential showed higher correlation with soil water potential than with the other environmental variables considered. Results indicate that these species have the capacity to adjust to summer drought conditions.
\end{abstract}

Key Words: Condalia microphylla, Larrea divaricata, Chuquiraga erinacea, Prosopis sp., drought tolerance, soil water, plant survival

Undesirable shrub invasion is one of the main problems of the semiarid phytogeographic region of Argentina known as the Caldén District (Cabrera 1976). This territory extends from southern San Luis through the center of La Pampa to southwest Buenos Aires province. Cow-calf operations are the primary economic activity in this area. Native pastures are the only source of grazing. The high stocking rates practised by traditional management usually tend to deteriorate soil and vegetation (Bóo and Peláez unpublished). One thus finds poorly managed pastures where the proportion of low value grasses and undesirable shrubs is very high (Cano 1975).

The climate diagram of Río Colorado (Río Negro province) $\mathbf{4 0}$ $\mathrm{km}$ southwest of the study area shows a relative drought period during summer (Fig. 1). Drought may also occur in winter, but with less intensity. These characteristics show that the regional range communities are closely linked to water availability.

Limited water results in stress, thus reducing plant growth either directly or indirectly.

The ecology and physiology of shrubs growing on rangelands are probably influenced more by water relations than by any other group of factors. Periodic water deficits are critical to growth in seasons when other factors such as light and temperature are favorable (Hass and Dodd 1970).

Authors are graduate researcher Centro de Recursos Naturales Renovables de la Zona Semiárida, and professor and research assistant, Comisión de Investigaciones Cientificas and Departamento de Agronomia, respectively. Universidad Nacional del Sur, 8000 Bahla Blanca, Argentina.

The authors gratefully acknowledge Dr. Osvaldo $A$. Fernaindez of the Centro de Recursos Naturales Renovables de la Zona Semiárida and the Departamento de Agronomia, Universidad Nacional del Sur, and Mr. David L. Anderson of the Instituto Nacional de Technologia Agropecuaria (INTA) for their valuable comments on the manuscript.

Manuscript accepted 6 March 1986

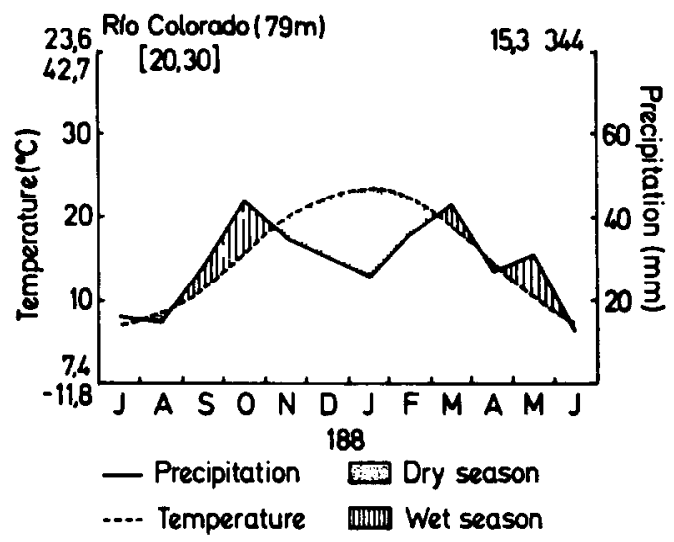

Fig. 1. Climate diagram of Rio Colorado ( $39^{\circ} 01^{\prime} S$ lat. and $64^{\circ} 05^{\prime} \mathrm{W}$ long.), Rio Negro province.

This study was undertaken in order to assess the seasonal plant water potential relationships of 5 of the most conspicuous shrubs of the Calden District and to relate these measurements to several environmental factors. Water relation values can give some indication of how adaptable these shrubs are to a semiarid environment.

\section{Description of the Study Area}

The site where the study was carried out is located in southeast La Pampa province $\left(38^{\circ} 45^{\prime} \mathrm{S}\right.$ lat. and $6^{\circ} 45^{\prime} \mathrm{W}$ long.). The sampling site is a 20 -ha area closed to grazing 12 years ago. The characteristic vegetation of this site is an open shrub stand including jarilla (Larrea divaricata), caldén (Prosopis caldenia), algarrobo ( $P$. flexuosa), and piquillín (Condalia microphylla). The most prominent grasses are flechilla negra (Piptochaetium napostaense) and flechilla fina (Stipa tenuis), both high forage value cool-season grasses. The climax community has totally disappeared and thus valuable species such as pasto de vaca (Sorghastrum pellitum), poa (Poa ligularis), and flechilla grande (Stipa clarazii) are very scarce or nonexistent (INTA et al. 1980).

Yearly average temperature is $15.3^{\circ} \mathrm{C}$. The mean temperature of the coldest month (June) is $7^{\circ} \mathrm{C}$, with a maximum mean of $13.8^{\circ} \mathrm{C}$ and a minimum mean of $2^{\circ} \mathrm{C}$. The warmest month is January with a mean of $23.6^{\circ} \mathrm{C}$, a maximum mean of $32.2^{\circ} \mathrm{C}$, and a minimum 


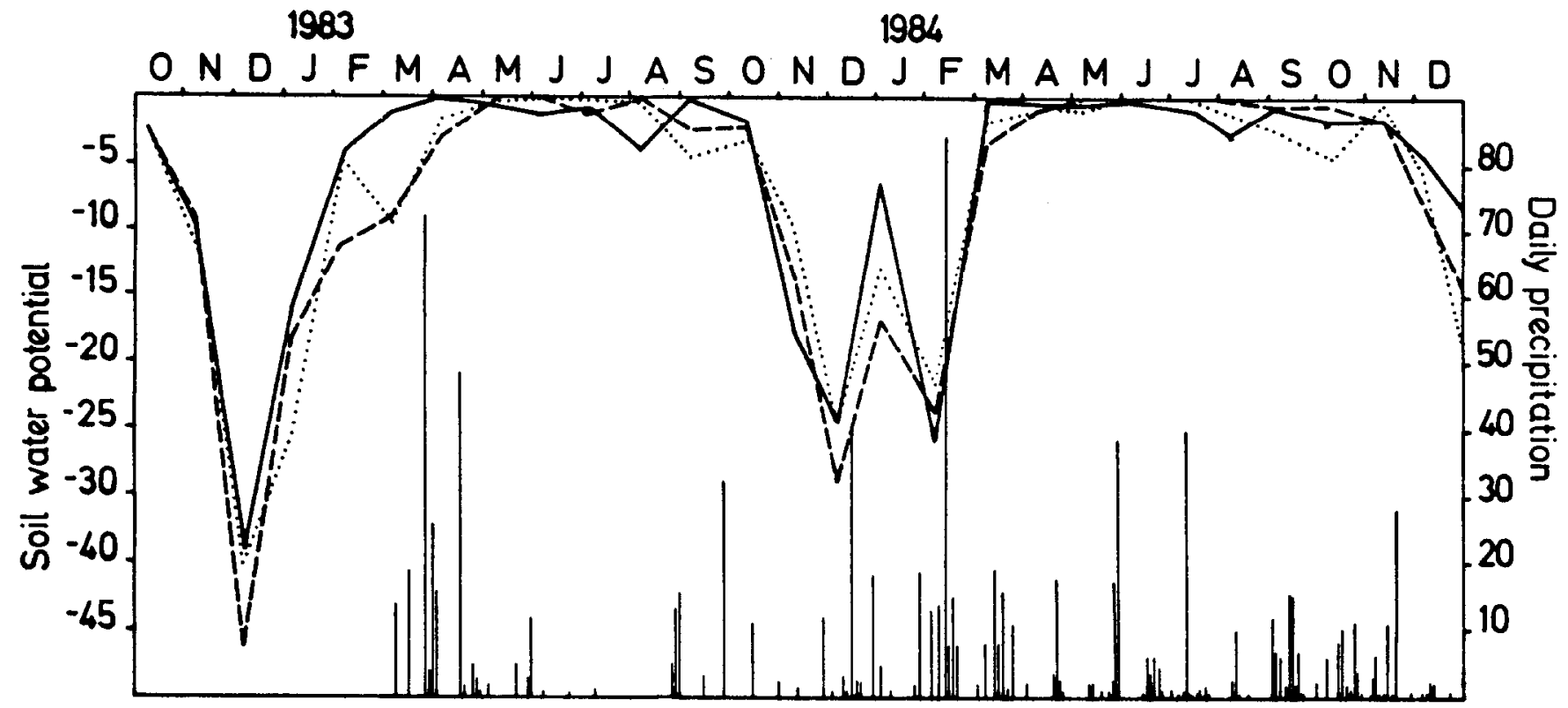

Fig. 2. Evolution of soil water potential (bars) at 30 (—), 50 (-——), and $70 \mathrm{~cm}$ (…) depth, and daily distribution of rainfall (mm) during the measurement cycle.

mean of $14.8^{\circ} \mathrm{C}$. For a period between the years 1941 and 1960 the absolute maximum temperature recorded was $42.7^{\circ} \mathrm{C}$ and the absolute minimum $-11.8^{\circ} \mathrm{C}$.

The relative mean humidity varied from maximum mean values in winter (June $76 \%$ ) to minimum mean values in summer (January 47\%).

Between the years 1971 and 1982 the average rainfall was 448 $\mathrm{mm}$, concentrated mostly in fall and spring. Average potential evapotranspiration was over $800 \mathrm{~mm} /$ year, with a negative water balance all year round.

Soil is a typical Paleorthid, well drained, with a medium to heavy texture and a local slope of 0.5 to $1 \%$. A petrocalcic horizon ("tosca") is found at an average depth of 40-60 cm (Sánchez, personal communication).

\section{Materials and Methods}

The hydric state of the soil was characterized by the measurement of water potential at 30,50 , and $70 \mathrm{~cm}$ depth. To determine soil water potential, 5 spanner thermocouple psychrometers with ceramic chambers (Dalton and Rawlins 1968, Easter and Sosebee 1974) were located at each depth. Individual calibration of each unit was achieved with sodium chloride $(\mathrm{Na} \mathrm{Cl})$ solutions of 0.1 , $0.3,0.5$, and 0.8 and 1.0 Molal with known water potential (Wiebe et al. 1971). The microvolt output for each was measured with a microvoltimeter. A regression equation was calculated for each thermocouple psychrometer, allowing conversion of the field recorded microvolt readings into water potential values expressed in bars. Soil temperature was also measured.

The dynamics of plant water potential for jarilla, caldén, algarrobo, piquillín, and chilladora (Chuquiraga erinacea) was measured by inserting a young branch of each species into a pressure bomb (Scholander et al. 1965). Measurements were made on 3 plants of each species from 9-10 a.m. and from 3-4 p.m. every 30 days during the growing season (from October until May).

Air temperature and relative humidity were recorded with a hygrometer, and the values were used to calculate vapor pressure deficit.

Precipitation was measured in the same working area with an automatic registering rain gauge.

The minimum water potential of each species, determined on each sampling date, was correlated (Snedecor and Cochran 1971) with the following environmental variables: minimum soil-moisture stress (maximum soil water potential), soil water potential at 30 , 50 , and $70 \mathrm{~cm}$ depth, vapor pressure deficit, and maximum soil and air temperatures.

\section{Results}

Precipitation during the study period exceeded the yearly average rainfall of $448 \mathrm{~mm}$ ( $521 \mathrm{~mm}$ in $1982,532 \mathrm{~mm}$ in 1983, and 632 $\mathrm{mm}$ in 1984).

The evolution of soil water potential (SWP) and daily distribution of rainfall during the measurement cycle are given in Figure 2.

Water availability decreased with increasing depth. This tendency was constant between 30 and $50 \mathrm{~cm}$ and between 30 and 70 cm, from October 1982 to April 1983, but became more erratic as of May 1983. Measurements for September and October 1983 and for January and May 1984 then reverted to the former constant trend. The SWP for the 3 levels decreased during spring, reaching its critical value at the end of this season or in the summer. The values of SWP throughout the period oscillated from saturation ( 0 bar) to a minimum of -41.4 bars recorded at a depth of $50 \mathrm{~cm}$ in December 1982.

An important amount of water was stored in the soil due to the high precipitation that occurred January (135 mm), March (130 $\mathrm{mm}$ ), and April (62 $\mathrm{mm}$ ) of 1983. As a consequence, high SWP values (greater than -5 bars) were recorded from April to October inclusive. A similar occurrence was observed from April through May 1984.

Plant water potential (plant WP) showed a similar pattern in all species. The afternoon values were lower than those obtained in the morning (Fig. 3 and 4). This was coincident with greater values of temperature and vapor pressure deficit (Fig. 5).

In the first growth cycle studied jarilla exhibited the greatest seasonal fluctuation of morning plant WP, which decreased from -11.2 bars in October to a minimum of -40 bars in December. For the period between 3 p.m. to 4 p.m. the greatest variation was found in algarrobo, whose plant WP oscillated between -35 bars in January and a maximum of -7.3 bars in March. In the 1983-1984 growth cycle, the highest fluctuation was observed in piquillin for the morning determination. Thus, values varied from a minimum of -40 bars in February to a maximum of -8.7 bars in March. With 

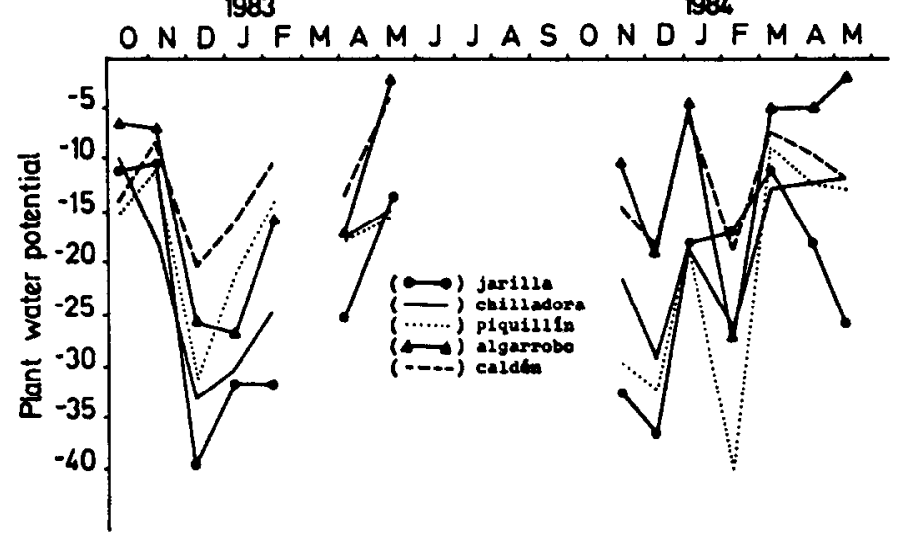

Fig. 3. Plant water potential (bars) for the period between 9 a.m. to 10 a.m.

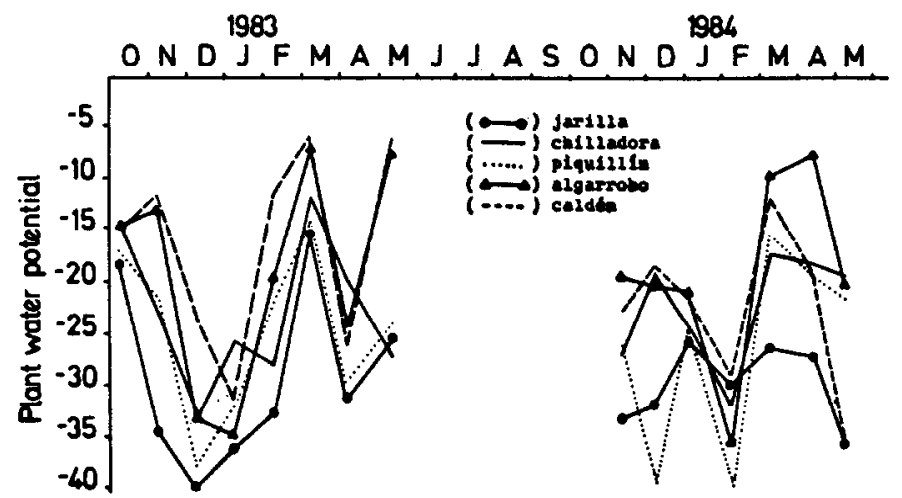

Fig. 4. Plant water potential (bars) for the period between 3 p.m. to 4 p.m.

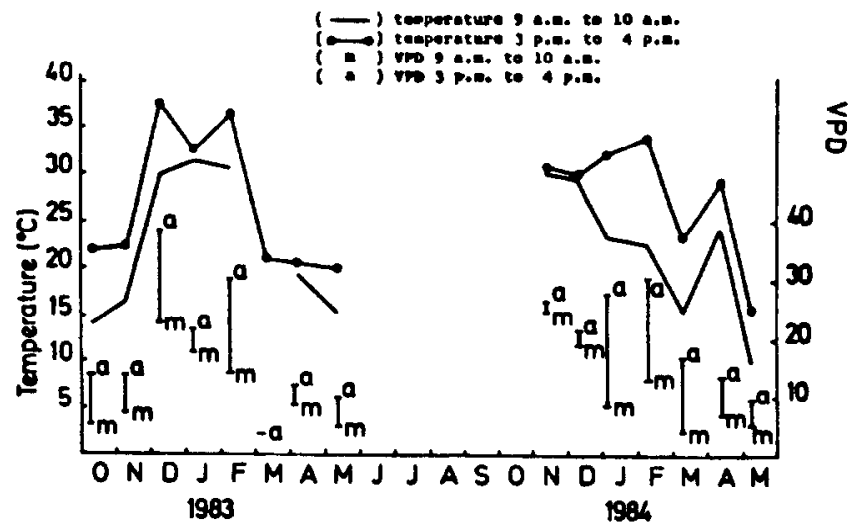

Fig. 5. Air temperature $\rho C$ ) and vapor pressure deficit $(\mathrm{mm})$.

recorded values varying from -35.6 bars in February to -7.7 bars in April, algarrobo exhibited the greatest fluctuation for the afternoon determinations.

The highest plant WP morning values were generally found in caldén and algarrobo, and the lowest afternoon values in jarilla. This trend remained constant during the first observation cycle and throughout most of second cycle (Fig. 3 and 4).

Afternoon precipitations occurred during January and December 1983, which affected the 3-4 p.m. determinations, causing increased plant WP values in chilladora and jarilla.

The lowest water potential of each species for each sampling date was correlated with different environmental variables. The simple linear correlation coefficient $(r)$ of plant WP with 7 measured variables is shown in Table 1. The plant water potential showed a
Table 1. Correlation coeficient of plant water potential with 7 measured variables.

\begin{tabular}{|c|c|c|}
\hline Species & Environmental Variables & $r$ \\
\hline Jarilla & $\begin{array}{l}\text { minimum soil-moisture stress } \\
\text { vapor pressure deficit } \\
\text { soil water potential at } 30 \mathrm{~cm} \\
\text { soil water potential at } 70 \mathrm{~cm} \\
\text { soil water potential at } 50 \mathrm{~cm} \\
\text { maximum air temperature } \\
\text { maximum soil temperature }\end{array}$ & $\begin{array}{l}.600^{*} \\
.560^{*} \\
.534^{*} \\
.479 \\
.476 \\
.389 \\
.212 \\
\end{array}$ \\
\hline Chilladora & $\begin{array}{l}\text { soil water potential at } 70 \mathrm{~cm} \\
\text { vapor pressure deficit } \\
\text { minimum soil-moisture stress } \\
\text { maximum air temperature } \\
\text { soil water potential at } 30 \mathrm{~cm} \\
\text { soil water potential at } 50 \mathrm{~cm} \\
\text { maximum soil temperature }\end{array}$ & $\begin{array}{l}.806 * \\
.800 * \\
.767 * \\
.673^{*} \\
.665 * \\
.584 * \\
.344 \\
\end{array}$ \\
\hline Piquillín & $\begin{array}{l}\text { soil water potential at } 30 \mathrm{~cm} \\
\text { minimum soil-moisture stress } \\
\text { soil water potential at } 50 \mathrm{~cm} \\
\text { soil water potential at } 70 \mathrm{~cm} \\
\text { vapor pressure deficit } \\
\text { maximum air temperature } \\
\text { maximum soil temperature }\end{array}$ & $\begin{array}{l}.870^{*} \\
.847 * \\
.792 * \\
.771 * \\
.685 * \\
.575 * \\
.423\end{array}$ \\
\hline Algarrobo & $\begin{array}{l}\text { soil water potential at } 30 \mathrm{~cm} \\
\text { soil water potential at } 70 \mathrm{~cm} \\
\text { minimum soil-moisture stress } \\
\text { vapor pressure deficit } \\
\text { soil water potential at } 50 \mathrm{~cm} \\
\text { maximum air temperature } \\
\text { maximum soil temperature }\end{array}$ & $\begin{array}{l}.753 * \\
.738 * \\
.724 * \\
.713 * \\
.698 * \\
.581 * \\
.490 *\end{array}$ \\
\hline Caldén & $\begin{array}{l}\text { soil water potential at } 30 \mathrm{~cm} \\
\text { vapor pressure deficit } \\
\text { minimum soil-moisture stress } \\
\text { soil water potential at } 70 \mathrm{~cm} \\
\text { soil water potential at } 50 \mathrm{~cm} \\
\text { maximum air temperature } \\
\text { maximum soil temperature }\end{array}$ & $\begin{array}{l}.384 \\
.343 \\
.337 \\
.330 \\
.282 \\
.192 \\
.185\end{array}$ \\
\hline
\end{tabular}

*Significant at $5 \%$ level.

significant correlation with the analysed soil water potential variations. Even though there was a similar trend for caldén, correlation coefficients were non-significant at $P=0.05$. For chilladora 2 parameters were closely related with plant WP: the vapor pressure deficit $(r=0.800)$ and SWP at $70 \mathrm{~cm}$ depth $(r=0.806)$. The air and soil maximum temperatures were, in general, the worst correlated variables with plant WP $(r \leq 0.673)$. The air and soil maximum temperatures are the highest measured on each sampling date for each category.

\section{Discussion}

Several authors have demonstrated that plant water potential undergoes daytime variations, exhibiting a maximum peak at dawn and a minimum at midday or in the first hours of the afternoon. In fact, Branson and Shown (1975) recorded the most critical water potential in big sagebrush (Artemisia tridentata) at 4 p.m.. Nielsen et al. (1981) found a similar trend in mesquite (Prosopis glandulosa) suggesting that this behavior is related to highest stomatal conductance, which occurs in morning hours in arid species.

The lowest plant water potential was better correlated with soil water potential in the present study. A close relationship between plant water potential and moisture stress in soil was demonstrated for Acacia aneura (Slatyer 1961) and between the plant moisture stress and soil moisture content for red pine (Pinus resinosa) (Sucoff 1972). However, Hass and Dodd (1972) reported the lack of influence of soil moisture upon the minimum and maximum 
water potential in mesquite. Branson and Shown (1975) found that minimum soil-moisture stress was the highest correlated variable with water stress in big sagebrush. Nevertheless, the same authors emphasized that when soil moisture is readily available for plants, above all in spring, then it is probably factors other than SWP that determine plant WP.

Maximum soil and air temperatures were poorly correlated with plant WP except in the case of chilladora, where maximum air temperature occupied an intermediate plane. Dina et al. (1973) found a highly significant correlation between these 2 variables and the water potential in shrubs belonging to a mountainous area of Utah (U.S.A.).

Vapor pressure deficit was one of the variables best correlated for chilladora. Hass and Dodd (1972) working with mesquite found highly significant correlations between plant water potential and vapor pressure deficit. However, Dina et al. (1973) detected significant correlations between these 2 parameters only in 1 of the 9 species.

The 5 species under study exhibited a plant WP recovery during the night. The values obtained earlier in the morning, were higher (less negative) than those recorded in afternoon hours. According to Sala et al. (1981) such plant behavior can been seen as an indication of plant response flexibility in the face of water stressinducing changes. $A$ wide range in plant $W P$ between morning and afternoon values would indicate a high degree of flexibility or a high capacity to return daily to relatively high water potentials. On the other hand, a narrow range between values would reveal situations of intensive stress. Two examples which can be used to illustrate the latter are the December 1982 and February 1984 data recordings for jarilla and piquillin. The plant WP values obtained on both dates for these species were of $\mathbf{- 4 0}$ bars in the morning and afternoon hours. The inability of jarilla and piquillin to daily recover their water potential affects the metabolic functions essential to their growth (Kozlowski 1972, Hsiao 1973, Fitter and Hay 1983), implying a higher susceptibility to water stress than the other 3 species studied here.

The water potential range of these shrub species as measured in the morning and afternoon hours suggests a relatively efficient adjustment to the conditions of summer drought. It is hypothesized that such behavior patterns facilitate the elimination of competition from other species, mainly those of the understory, in periods of long or intensive drought. According to Vallentine (1974) drought may be an important cause of undesirable plant invasions on ranges previously weakened by grazing or other factors.

Minimum plant water potential is better correlated with soil water potential for the different forms. Branson and Shown (1975) suggested that the highly significant correlation of internal plant stress with lowest soil-moisture stress indicates that rapid and inexpensive plant-stress measurements might be used to estimate minimum soil-moisture stress.

\section{Literature Cited}

Bóo, R.M., and D.V. Peláez. Unpublished. Comunidades vegetales del sur del Distrito del Caldén.

Branson, F.A., and L.M. Shown. 1975. Soil-moisture stress related to plant-moisture stress in big sagebrush. J. Range Manage. 28:212-215.

Cabrera, A.L. 1976. Regiones fitogeográficas argentinas. Enciclopedia Argentina de Agricultura y Jardinería. Tomo II. Fasc. 1. Acme S.A.C.I. Buenos Aires.

Cano, E.A. 1975. Pastizales en la regioín central de la provincia de La Pampa. I.D.I.A. julio-septiembre 1975:1-15.

Dalton, F.N., and S.L. Rawlins. 1968. Design criteria for peltier-effect thermocouple psychrometers. Soil Science 105:12-17.

Dina, S.J., L.G. Klikoff, and M.B. Keddington. 1973. Seasonal water potential patterns in the mountain brush zone Utah. Amer. Mid. Natur. 89:234-239.

Easter, J.S., and R.E. Sosebee. 1974. Use of thermocouple psychrometry in field studies of soil-plant-water relationships. Plant and Soil 40:707-712.

Fitter, A.H., and R.K.M. Hay. 1983. Environmental physiology of plants. Academic Press. London.

Hass, R.H., and J.D. Dodd. 1970. Seasonal water stress pattern in honey mesquite. Brush Research in Texas/1970:59-62.

Hass, R.H., and J.D. Dogg. 1972 Water-stress patterns in honey mesquite. Ecology 53:674-680.

Hsiao, T.C. 1973. Plant responses to water stress. Ann. Rev. Plant Physiology 24:519-570.

Instituto Nacional de Teenología Agropecuaria, Prov. de la Pampa, y Univ. Nac. de La Pampa. 1980. Inventaro integrado de los recursos naturales de la provincia de La Pampa. ISAG. Buenos Aires.

Kozlowsky, T.T. 1972. Wildland shrubs-their biology and utilization. Internat. Symp. Utah State Univ. Logan. July 1971. Intermountain Forest and Range Exp. Sta. 229-244.

Nielsen, E.T., P.W. Rundel, and M.R. Sharifi. 1981. Summer water relations of the desert phreatophyte Prosopis glandulosa in the Sonoran Desert of southern California. Oecologia (Berlin) 50:271-276.

Sala, O., A. Soriano, and S. Perelman. 1981. Relaciones hídricas de algunos componentes de un pastizal de la depresión del Salado. Rev. Facultad de Agronomia 2:1-10.

Scholander, P.F., H.T. Hammel, E.D. Bradstreet, and E.A. Hemmingsen. Sap pressure in vascular plants. Science 148:339-346.

Slatyer, R.O. 1961. Internal water balance of Acacia aneura F. Muell. in relation to environmental conditions. In: Plant-water relationships in arid and semi-arid conditions. Madrid Symp. Proc., Paris. UNESCO: 137-146.

Snedecor, G.W., and W.G. Cochran. 1971. Métodos estadisticos. CECSA

Sucoff, E. 1972. Water potential in red pine: soil moisture, evapotranspiration, crown position. Ecology 53:681-686.

Vallentine, J.F. 1974. Range development and improvements. Brigham Young Univ. Press, Provo.

Wiebe, H.H., G.S. Campbell, W.H. Gardner, S.L. Rawlins, J.W. Cary, and R.W. Brown. 1971. Measurement of plant and soil water status. Bull. 484 Utah Agr. Exp. Sta. 